\title{
EDITORIAL
}

\section{A 100 AÑOS DE LA REFORMA DE CÓRDOBA.}

La Promoción 2017 de la Universidad Nacional de Asunción ha recibido su nombre en un homenaje merecido y justo al Centenario de la Reforma de Córdoba.

Este hecho histórico ha marcado a la Universidad latinoamericana tradicional; por ello, es y será recordado por haber dado el puntapié para el ingreso a un nuevo tiempo, un tiempo de democracia, de libertades y de emancipación.

El Movimiento de Córdoba, iniciado en 1918, cuyo logro principal fue la obtención de la autonomía universitaria y, no de menor importancia, otros avances como la elección de los cuerpos directivos y de las autoridades de la Universidad por la propia comunidad universitaria así como la participación de sus elementos constitutivos, profesores, estudiantes y graduados, en la composición de sus organismos de gobierno; los concursos de oposición para la selección del profesorado y la periodicidad de las cátedras; la docencia libre; la gratuidad de la enseñanza; la democratización del ingreso a la universidad; la extensión universitaria, el fortalecimiento de la función social de la Universidad, la proyección al pueblo de la cultura universitaria y la preocupación por los problemas nacionales.

Al cumplirse el Centenario de la Reforma de Córdoba, la plena vigencia de las reivindicaciones puede constatarse en el rango constitucional que adquiere la autonomía universitaria, la libertad de enseñanza y la libertad de cátedra, Artículo 79 de nuestra Carta Magna; además, el novel Estatuto sancionado y puesto en vigencia el 5 de diciembre de 2017 y los diversos reglamentos que actualmente se encuentran en estudio contemplan en sus articulados los preceptos adquiridos durante el Movimiento de Córdoba. Sin embargo, y a pesar de todo cuanto se ha avanzado, todavía podemos decir que "los dolores que quedan son las libertades que faltan" y asumir el compromiso de construir y avanzar consagrando la vida a la búsqueda de la verdad.

Por último, la responsabilidad de defender el paradigma de la Reforma de Córdoba implica llegar a posiciones filosóficas, lo que en el mundo universitario significa pronunciarse a favor de políticas de estado que promuevan las transformaciones necesarias para desplegar el potencial de la UNA.

Prof. Dra. Elizabeth Nuñez Grüner, M.Sc Directora de la Revista "Compendio de Ciencias Veterinarias" 


\section{EDITORIAL}

\section{YEARS AFTER THE CORDOBA REFORM.}

The 2017 Promotion of the National University of Asunción has received its name in a well deserved homage to the Centennial of the Cordoba Reform.

This historical fact has marked the traditional Latin American University; for that reason, it is and will be remembered for having given the kick to enter a new time, a time of democracy, liberties and emancipation.

The Cordoba Movement, initiated in 1918, whose main achievement was the achievement of university autonomy and, not least, other advances such as the election of the governing bodies and the authorities of the University by the university community itself as well as the participation of its constituent elements, professors, students and graduates, in the composition of its governing bodies; the competitions of opposition for the selection of the faculty and the periodicity of the chairs; free teaching; the gratuity of teaching; the democratization of entry to the university; the university extension, the strengthening of the social function of the University, the projection of the university culture to the people and the concern for the national problems.

At the fulfillment of the Centennial of the Cordoba Reform, the full validity of the claims can be seen in the constitutional range that acquires university autonomy, freedom of education and academic freedom, Article 79 of our Constitution; In addition, the novel Statute sanctioned and put into effect on December 5 , 2017 and the various regulations currently under study contemplate in their articles the precepts acquired during the Cordoba Movement.

However, and despite all that has been advanced, we can still say that "the pains that remain are the freedoms that are missing" and assume the commitment to build and advance consecrating life to the search for truth.

Finally, the responsibility of defending the paradigm of the Cordoba Reform implies reaching philosophical positions, which in the university world means to pronounce in favor of state policies that promote the necessary transformations to unfold the potential of the UNA.

Prof. Dra. Elizabeth Nuñez Grüner, M.Sc Directora de la Revista "Compendio de Ciencias Veterinarias" 